\title{
A RAPID METHOD FOR DETERMINING BLOOD VOLUMES BY THE USE OF P'2-LABELLED RED CELLS
}

\author{
BY ALLEN F. REID AND MARJORIE K. ORR \\ (From the Department of Biophysics and Physical Chemistry, Baylor University Graduate \\ Research Institute and Department of Biophysics, Southwestern Medical School, \\ University of Texas, Dallas, Texas)
}

(Received for publication September 30, 1949)

The conventional method of determining blood volumes is to inject a substance into the circulatory system, allow time for mixing, withdraw a blood sample, and measure the dilution of the substance.

Circulating blood volume has been indirectly determined from the plasma volume and the hematocrit figure. These procedures, utilizing the dilution of dyes or the dilution of albumin in plasma to determine the plasma volume, have various shortcomings and admit appreciable error (1-7). Cell volumes have been determined by the use of carbon monoxide-labelled cells. However, the validity of the results is subject to question (8-12). The methods using radioactive ironlabelled cells, because of technical difficulties, are of little value as routine clinical procedures $(1,4$, 8, 13-19). It has been shown, however, that radioisotope-labelled cell methods are more-accurate than plasma dye methods (4).

The initial use of radioactive phosphorus in blood volume determination was, like the use of radioactive iron, in the synthesis of tagged cells in a donor animal (20). The involved and time consuming labelling was simplified upon discovery that the cells could be labelled with a satisfactory degree of stability by incubation for a short time with inorganic $P^{32}(3)$. Since then, several investigators $(2,3,6,7,20-29)$ have used cells labelled with $\mathrm{P}^{32}$ in this manner for blood volume determinations. These determinations, although comparing very favorably with analyses by the earlier methods, still lack the ease of manipulation and precision to recommend them to routine clinical application.

This paper presents a method of utilizing $\mathrm{P}^{32}$ labelled red cells in a convenient procedure for determining accurate circulation blood volumes.

\section{METHOD}

In brief, the method consists of $(a)$ incubating red cells with $\mathrm{P}^{32}$ until a sufficient amount of $\mathrm{P}^{32}$ has been incorporated by the cells; $(b)$ injecting a suspension of the washed cells into the subject, waiting for uniform distribution of the cells in the circulating blood, and withdrawing a sample; and (c) measuring the relative radioactivity of the cells in the injected sample and the withdrawn sample.

Procedure. A sample of about 100 microcuries of $\mathbf{P}^{32}$ in physiological saline solution is injected into a $10 \mathrm{ml}$. vacuum blood sample tube, ${ }^{1}$ taking care to exclude contaminating air. Several such tubes may be prepared and held until such time as they are needed. Six to $8 \mathrm{ml}$. of the subject's blood is drawn in a sterile heparinized syringe and injected into the tube. The tube is incubated at $37^{\circ} \mathrm{C}$. for 30 minutes. It is then centrifuged and the plasma is removed without disturbing the cells. This is accomplished by introducing a short 15-gauge needle through the stopper and withdrawing the plasma by means of a 4 inch 22 -gauge needle and syringe. Sterile physiological buffer is added in the same quantity. The 15-gauge needle is covered with a No. 1 vaccine bottle cap and remains in place while the contents of the tube are mixed and centrifuged. The supernatant is again drawn off. This washing procedure is repeated. The cells are then suspended in sterile buffer solution and drawn off in a $10 \mathrm{ml}$. syringe calibrated to $5 \mathrm{ml}$. A portion is emptied into a fresh test tube and the remaining $5 \mathrm{ml}$., accurately measured, is injected into the subject. Adsorption on the glass of the tube of $\mathrm{P}^{32}$ from the labelled cells is negligible in a reasonable period of time.

After from 10 to 20 minutes a $10 \mathrm{ml}$. sample of blood is taken in a heparinized syringe. The sample may be kept in a standard blood sample tube until convenient for measuring. A lusteroid cup is filled to the mark with the whole blood and its radioactivity measured with a Geiger counter. The original cell suspension is prepared for measurement by hemolyzing with water and making up to 400 times its original volume with $18 \%$ glucose. A second cup is filled with this and its radioactivity measured. Routine corrections for the Geiger counter measurements are made (30). The blood volume is calculated from these relative measurements :

1 "Vacutainer" from Becton Dickinson \& Co., Rutherford, N. J. 
Blood volume $=400 \times$ volume injected

$$
\times \frac{\text { activity of glucose sample }}{\text { activity of whole blood sample }} \text {. }
$$

If cell volume or plasma volume is desired an hematocrit should be done. If advisable, the size of blood sample may be reduced.

Reagents and equipment. The wash solution is sterile, pyrogen-free buffer ( $\mathrm{pH}$ 7.4) physiological to sodium phosphate and sodium chloride.

Equipment for measurement of blood under the Geiger counter is diagrammed in Figure 1. Lusteroid cups holding 8-9 ml. are made by cutting off the bottom $15-20 \mathrm{~mm}$. of lusteroid centrifuge tubes. A cuff of the same material is cemented around the top of the cup. High precision in manufacture is not necessary, as the extent of the cup above and below the bottom of the cuff may vary without affecting the counting rate of a sample placed at a standard level. Such a standard level may be conveniently made by filling the cup to the bottom of the cuff and resting the cuff on the ledge of a standard position tray.
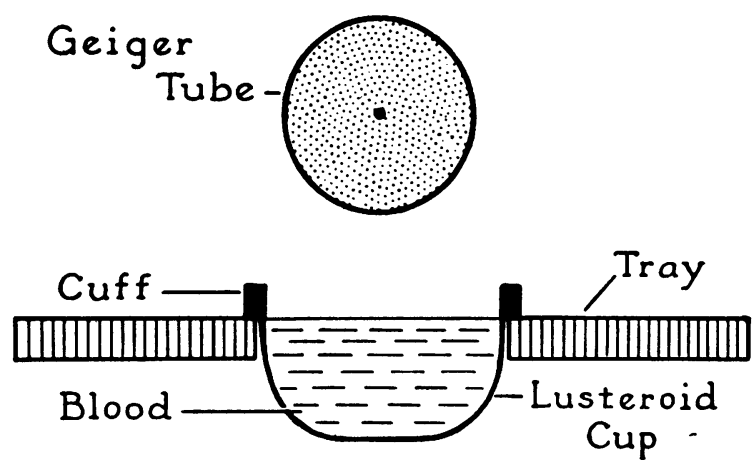

Fig. 1. Cross Section of Counting Arrangement for Whole Blood

DISCUSSION

Blood volume determination by this method makes use of the subject's own blood cells labelled by incubation with $\mathrm{P}^{32}$, a convenience utilized by several other investigators $(3,6,7,26-29,31)$. This eliminates the necessity of synthesis in a donor and the transfer of a large volume of blood. As in other methods of blood volume determination, it is necessary to assume that the sample hematocrit is representative of the circulating blood hematocrit. No claim is made on this controversial issue and no attempt has been made at clarification.

Modifications introduced in these laboratories include washing of the labelled cells before injection and measurement of the whole blood. This eliminates the errors described by Kelly et al. (7) due to (a) transfer of $P^{32}$ from the plasma into the red blood cells after injection; since no appreciable amount of $\mathrm{P}^{32}(0.01 \%$ to $0.03 \%)$ is left in the suspension medium after washing, no error is introduced by this; (b) loss of $P^{32}$ from the blood cells after withdrawal before preparation of the sample for counting; since the measurement is made on the whole blood, any $\mathrm{P}^{32}$ so lost is still counted; (c) plasma adhering to the cells; (d) hemolysis of the labelled blood cells; here again, any $\mathrm{P}^{32}$ released is measured.

Other methods of measurement of $\mathrm{P}^{32}$ in blood have depended on drying or ashing the samples. The use of an "infinitely" thick sample for whole blood measurement eliminates difficult and timeconsuming procedures in preparation of the samples. An "infinitely" thick sample is one thick enough so that only a negligible fraction of the particles given off from the bottom surface can penetrate through the top surface to be counted. Measurement of such a sample eliminates errors in the $\beta$-ray absorption correction, which cannot be neglected and which is very difficult to standardize for accurate determination of dried or ashed blood samples. If a standard surface area is exposed, the measurement gives directly the activity per unit volume of the solution and is independent of the size of the sample (30). In the case of $\mathrm{P}^{32}$, the range of the most energetic $\beta$-rays is about $6.7 \mathrm{~mm}$. (32). In order to check experimentally the validity of the technique, cups were filled to depths of 7,13 , and $19 \mathrm{~mm}$. with the same solution of $\mathrm{P}^{32}$ in glucose, and measured for 30 minutes. The results were :

$\begin{aligned} 7 \mathrm{~mm} . & 174,682 \text { counts } \\ 13 \mathrm{~mm} . & 173,510 \text { counts } \\ 19 \mathrm{~mm} . & 173,248 \text { counts. }\end{aligned}$

This shows agreement within the statistical error of counting.

Eighteen $\%$ glucose solution is used as a diluent because its density approximates that of whole blood. The cells remain suspended in the solution for an adequate counting period, and the $\beta$-ray absorption is comparable to that of the whole blood. To measure samples of blood with an extremely high sedimentation rate, dilution with an equal volume of the glucose solution eliminates the need of frequent stirring during an extended Geiger counter measurement.

Several in vitro experiments were conducted 
to determine the percentage of recovery with a known blood dilution factor. Results indicated that recovery was quantitative.

A typical experiment follows:

A bottle of freshly drawn bank blood was tapped with a needle and syringe for $6 \mathrm{ml}$. of blood which were placed in a vacuum tube with approximately 100 microcuries $\mathrm{P}^{32}$. This tube was incubated at $37^{\circ} \mathrm{C}$. for 30 minutes, centrifuged and the supernatant removed, following the technique described. The cells were washed twice with physiological buffer. An accurately measured aliquot of the resuspended cells $(1.00 \mathrm{ml}$.) was added to the original bottle of blood. After shaking for 10 minutes to insure complete mixing, a sample was withdrawn for Geiger counter measurement. This was compared to a portion of the washed cell suspension which had been diluted 1:400 with $18 \%$ glucose.

Radioactivity of original cells diluted with glucose$160 \times 64 \mathrm{c} / \mathrm{m}$

Radioactivity of blood sample-104 $\times 64 \mathrm{c} / \mathrm{m}$

Calculated blood volume $\frac{160 \times 400}{104}=615 \mathrm{ml}$.

Measured blood volume $=604 \mathrm{ml}$.

Since numerous investigators have compared radioactive methods with dye and other blood volume methods (1), no formal series was run for this purpose. However, over 60 blood volume determinations on humans have been run using this method and the results were compatible with the clinical findings.

A typical case follows :

The blood volume of a $65 \mathrm{~kg}$. white male (diagnosis: polycythemia vera) was determined. Eight $\mathrm{ml}$. of blood were drawn under aseptic conditions and incubated with approximately 100 microcuries of $\mathrm{P}^{32}$. The cells were washed twice and resuspended in physiological buffer. Five $\mathrm{ml}$. of the cell suspension were injected into the patient. The remainder of the cell suspension was saved for measurement. After 15 minutes a sample of blood was drawn from the patient and its radioactivity measured directly.

Radioactivity of original cells diluted with glucose$197 \times 64 \mathrm{c} / \mathrm{m}$

Radioactivity of whole blood sample- $56 \times 64 \mathrm{c} / \mathrm{m}$

Calculated blood volume $=400 \times 5 \times \frac{197}{56}=7,090 \mathrm{ml}$.

Following the conventional pattern of blood volume determination set by many investigators, a time of mixing of 10 to 20 minutes is considered adequate for most cases (26). Accordingly, no series was run to determine mixing time.

One hundred microcuries of $\mathrm{P}^{32}$ were used so as to give a radioactivity of the blood convenient for analysis yet not dangerous to the patient. In a series of 110 individuals studied for $\mathrm{P}^{\mathbf{3 2}}$ uptake (17 normal and 93 hospitalized for a variety of conditions) the highest $\mathrm{P}^{32}$ uptake by the blood cells was $19.5 \%$ and the lowest $1.7 \%$ of that incubated under the conditions of the method. The average was a $7 \%$ uptake. A $20 \%$ uptake as the maximum for an individual would correspond to a total irradiation in a $50 \mathrm{~kg}$. person of 0.07 rep for the first week if there were no excretion, and would diminish thereafter with a half-life of about two weeks. This is in only a small fraction of the generally accepted permissible level of radiation ( 0.5 rep). Routine performance of analyses by this method admits of no radiation hazard to the technician or physician if ordinary precautions are used.

\section{SUMMARY}

A simple method is described for the determination of circulating blood volume, using red blood cells labelled with radioactive phosphorus and washed after injection. The radioactivity of the whole blood is measured, using standard Geiger counter equipment. Several errors and time-consuming procedures inherent in other methods using this tracer have been eliminated.

\section{BIBLIOGRAPHY}

1. Chapin, M. A., and Ross, J. F., Determination of true cell volume by dye dilution, and by protein dilution, and with radioactive iron. Error of centrifuge hematocrit. Am. J. Physiol., 1942, 137, 447.

2. Anderson, R. S., The use of radioactive phosphorus for determining circulating erythrocyte volumes. Am. J. Physiol., 1942, 137, 539.

3. Nylin, G., Studies on the circulation with the aid of blood corpuscles labelled with radioactive phosphorus compounds. Ark. fur Kemi, Minerologi och Geologi, 1945, A 20, 17.

4. Gibson, J. G., 2nd, Peacock, W. C., Seligman, A. M., and Sack, T., Circulating red cell volume measured simultaneously by the radioactive iron and dye methods. J. Clin. Invest., 1946, 25, 838.

5. Meneely, G. R., Wells, E. B., and Hahn, P. F., Application of the radioactive red cell method for determination of blood volume in humans. Am. J. Physiol., 1947, 148, 531.

6. Nylin, G., and Hedlund, S., Weight of the red blood corpuscles in heart failure determined with labelled erythrocytes during and after decompensation. Am. Heart J., 1947, 33, 770. 
7. Kelly, F. J., Simonsen, D. H., and Elman, R., Blood volume determination in the human with red cells containing radioactive phosphorus ( $\mathbf{P}^{32}$ ) and with pure human albumin. J. Clin. Invest., 1948, 27, 795.

8. Gibson, J. G., 2nd, Weiss, S., Evans, R. D., Peacock, W. C., Irvine, J. W., Jr., Good, W. M., and Kip, A. F., The measurement of the circulating red cell volume by means of two radioactive isotopes of iron. J. Clin. Invest., 1946, 25, 616.

9. Smith, H. P., Arnold, H. R., and Whipple, G. H., Blood volume studies. VII. Comparative values of Welcker, carbon monoxide and dye methods for blood volume determinations; accurate estimations of absolute blood volume. Am. J. Physiol., 1921, 56, 336.

10. Chang, H. C., and Harrop, G. A., Jr., The determination of the circulating blood volume with carbon monoxide. J. Clin. Invest., 1927-28, 5, 393.

11. Hopper, J., Jr., Tabor, H., and Winkler, A. W., Simultaneous measurements of the blood volume in man and dog by means of Evans Blue dye, T-1824, and by means of carbon monoxide. I. Normal subjects. J. Clin. Invest., 1944, 23, 628.

12. Hopper, J., Jr., Winkler, A. W., and Elkinton, J. R., Simultaneous measurements of the blood volume in man and dog by means of Evans Blue dye, T-1824, and by means of carbon monoxide. II. Under $a b-$ normal conditions including secondary shock. $\mathrm{J}$. Clin. Invest., 1944, 23, 636.

13. Hahn, P. F., Balfour, W. M., Ross, J. F., Bale, W. F., and Whipple, G. H., Red cell volume, circulating and total, as determined by radio iron. Science, 1941, 93, 87.

14. Hahn, P. F., Bale, W. F., and Balfour, W. M., Radioactive iron used to study red blood cells over long periods. The constancy of the total blood volume in the dog. Am. J. Physiol., 1941-42, 135, 600.

15. Hahn, P. F., Ross, J. F., Bale, W. F., Balfour, W. M., and Whipple, G. H., Red cell and plasma volumes (circulating and total) as determined by radio iron and by dye. J. Exper. Med., 1942, 75, 221.

16. Hahn, P. F., and Bale, W. F., Linear relationship between the circulating red cell mass and the venous hematocrit as determined with radioactive iron. Am. J. Physiol., 1942, 136, 314.

17. Peacock, W. C., Evans, R. D., Irvine, J. W., Jr., Good, W. M., Kip, A. F., Weiss, S., and Gibson, J. G., 2nd, The use of two radioactive isotopes of iron in tracer studies of erythrocytes. J. Clin. Invest., 1946, 25, 605 .

18. Gibson, J. G., 2nd, Seligman, A. M., Peacock, W. C., Aub, J. C., Fine, J., and Evans, R. D., The distri- bution of red cells and plasma in large and minute vessels of the normal dog determined by radioactive isotopes of iron and iodine. J. Clin. Invest., 1946, 25, 848.

19. Meneely, G. R., Wells, E. B., and Hahn, P. F., Application of the radioactive red cell method for determination of blood volume in humans. Am. J. Physiol., 1947, 148, 531.

20. Hahn, L., and Hevesy, G., A method of blood volume determination. Acta physiol. Scandinav., 1940, 1, 3.

21. Hahn, L., and Hevesy, G., Rate of penetration of ions into erythrocytes. Acta physiol. Scandinav., 1942, 3, 193.

22. Brown, F. A., Jr., Hempelmann, L. H., Jr., and Elman, R., The determination of blood volume with red blood cells containing radioactive phosphorus $\left(\mathrm{P}^{32}\right)$. Science, 1942, 96, 923.

23. Govaerts, J., and Lambrechts, A., Etude sur le volume sanguin. Methode de mesure du volume chez 1'homme et le chien a l'aide du radio-pyosphore. Acta. Biologica Belgica, 1942, 11, 425.

24. Hevesy, G., and Zerahn, K., Determination of the red corpuscle content. Acta physiol. Scandinav., 1942, 4, 376.

25. Nylin, G., and Malm, M., Concentration of red blood corpuscles containing labelled phosphorus compounds in the arterial blood after intravenous injection. Am. J. Med. Sc., 1944, 207, 743.

26. Nylin, G., The dilution curve of activity in arterial blood after intravenous injection of labelled corpuscles. Am. Heart J., 1945, 30, 1.

27. Nylin, G., Blood volume determinations with radioactive phosphorus. Brit. Heart J., 1945, 7, 81.

28. Nylin, G., Circulatory blood volume of some organs. Am. Heart J., 1947, 34, 174.

29. Nylin, G., The effect of heavy muscular work on the volume of circulating red corpuscles in man. Am. J. Physiol., 1947, 149, 180.

30. Reid, A. F., Detection and measurement of radioactive tracers, in: Preparation and Measurement of Isotopic Tracers. Edwards, Ann Arbor, Michigan, 1948, p. 83.

31. Taylor, F. H. L., Levenson, S. M., and Adams, M. A., Study of phosphorus metabolism in man: a study of the permeability of the human erythrocyte to inorganic phosphate in vitro by the use of radioactive phosphate $\left(\mathrm{P}^{32}\right)$. Blood, 1948, 3, 1472.

32. Hevesy, G., Radioactive Indicators: Their application in Biochemistry, Animal Physiology, and Pathology. Interscience, New York, 1948. 